\title{
КОМПОЗИЦИОННЫЙ МАТЕРИАЛ НА ОСНОВЕ СЕРЫ И СЕРОСОДЕРЖАЩИХ ОТХОДОВ
}

\author{
Булай T.B.
}

Гродненский государственный университет имени Янки Купаль

\begin{abstract}
: the article presents the main promising areas for the use of sulfur and the technological process for producing sulfur concrete. Experimental data on the physical and mechanical properties of sulfur concrete, such as strength and water absorption, are given.
\end{abstract}

Композиционные материалы, изготовленные с использованием серы и серосодержащих отходов отличаются рядом положительных качеств, в сравнении с другими аналогичными материалами. К ним относят: быстрый набор прочности; возможность вторичной переработки материалов; стойкость к воздействию агрессивных сред; способность твердения смесей при низких температурах; быстрая оборачиваемость форм; низкая электро- и теплопроводность; водонепроницаемость; повышенная морозостойкость и износостойкость.

Существуют отдельные недостатки серного бетона, которые могут отрицательно сказаться на широком его использовании: высокая температура $\left(140^{\circ} \mathrm{C}\right)$ для приготовления смесей; высокая цена установки для выпуска изделий; высокая токсичность производства (выделение сероводорода); низкая термостойкость $\left(+90^{\circ} \mathrm{C}\right)$. Эти недостатки можно устранить четким соблюдением технологии производства.

Технология производства серного бетона заключается в разогреве серного вяжущего до $120-140^{\circ} \mathrm{C}$ с последующим совмещением с минеральными компонентами и формирование изделий необходимой формы. Твердение происходит в процессе остывания горячей смеси и переходом её в твердую структуру. Затвердевшая смесь при повторном нагреве восстанавливает первоначальную подвижность.

Исследования серного бетона проводились в несколько этапов.

Первоначально испытания прочности осуществлялись на образцах, изготовленных из серы и песка. Предел прочности на сжатие находился в пределах от 45,3 до 53 МПа. Далее в исследуемый состав был введен отсев гранитного щебня различных фракций. Результаты показали, что прочность колеблется в пределах от 5,40 до 14,67 МПа, что гораздо ниже значений прочности образцов, изготовленных ранее из серы и песка, принятых за эталонные. На втором этапе состав сера + гранитные отсевы был дополнен введением песка в различных процентных соотношениях по отношению к исходным компонентам. В результате наблюдали увеличение прочности образцов до 26,6 МПа.

Далее проводилось исследование водопоглощения образцов, изготовленных из серы и песка, серы и гранитных отсевов, серы, гранитных отсевов и песка в возрасте 360 суток. Результаты показали, что водопоглощение колеблется в диапазоне соответственно от 0,01 до $0,52 \%, 0,1$ до $0,86 \%$ и от 0,22 до $1,3 \%$, что гораздо ниже, чем у традиционных бетонов на портландцементном вяжущем, составляющем 4,7-5,7\%.

При замене серы на серосодержащие отходы (серный шлам) исследования показали, что предел прочности на сжатие достигает 69,18 МПа, а водопоглощение - 0,73\%.

Исследования свойств композиционного материала на основе серы и серосодержащих отходах показал, что материал может набирать прочность на пылеватых фракциях песка, что для обычного бетона является невозможным. Исследования водопоглощения образцов подтвердили, что сера обладает гомогенной структурой и обеспечивает плотное расположение молекул относительно друг друга. Присутствие наполнителя приводит к тому, что молекулы серы сцепляют молекулы наполнителя и заполняют внутреннее пространство получаемого вещества таким образом, что пористость становится почти равной нулю. Замена серы на серный шлам позволит решить проблему утилизации серосодержащих отходов, образующихся на предприятиях химической промышленности, снизить вредное воздействие на окружающую среду, повысить эффективность производства и снизить стоимость полученного материала. 